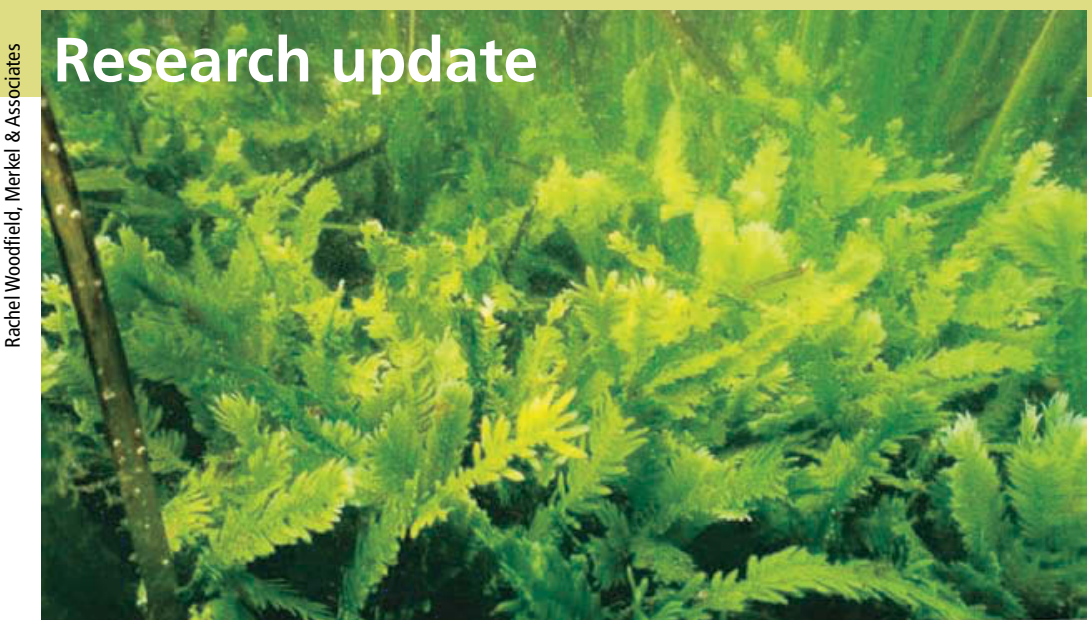

\section{Killer algae under control, for now}

cientists are cautiously optimistic that the $\checkmark$ nation's first outbreak of "killer algae" - a nonnative seaweed called Caulerpa taxifolia that was discovered in two Southern California coastal harbors in June 2000 - is under control, due to an aggressive response by multiple agencies, including California Sea Grant.

Caulerpa is a decorative aquarium plant with feathery green fronds. The outbreaks, in Agua Hedionda Lagoon in northern San Diego County and Huntington Harbour in Orange County, were likely caused by someone dumping a home saltwater aquarium into a waterway.

California Sea Grant participated in the Southern California Caulerpa Action Team or SCCAT, a statewide effort to prevent the highly invasive, saltwater seaweed from spreading as it has in the Mediterranean, with devastating consequences for marine life.

As of September 2003, Caulerpa had not been detected for 12 months in Agua Hedionda Lagoon and 9 months in Huntington Harbour. "We're very optimistic that we probably will be able to eradicate Caulerpa from these two systems," says Bob Hoffman of the National Marine Fisheries Service (NMFS).

Caulerpa's ability to grow rapidly over boulders, seawalls, in mud, sand or on rocks has the effect of severely reducing populations of native seaweeds and grasses. Because fish, invertebrates and seabirds need native habitats to survive (see page 104), Caulerpa outbreaks dull the biological richness of marine ecosystems.

Caulerpa presents a global threat to marine ecosystems. From just 1 square meter in the mid-1980s, more than 32,000 acres of the Mediterranean Sea floor is now smothered by the weed. In the last 5 years, the alga has spread to North Africa and Australia (both of which also have native Caulerpa species) and California. Genetic tests have shown that Caulerpa specimens in California and the Mediterranean are clones of specimens cultured and dis-
A highly invasive seaweed, Caulerpa taxifolia was discovered among eelgrass shoots in Agua Hedionda Lagoon in Carlsbad, left. Vast, feathery carpets of the green alga cover the bottom of the Mediterranean, but biologists are cautiously optimistic that its spread is under control in California.

played at the Stuttgart Museum in Germany in the early 1980s.

California Sea Grant funded several projects to reinforce and expand the SCCAT program. Susan Williams, director of the Bodega Bay Marine Lab of UC Davis, mapped out the potential geographic range of Caulerpa based on available light, salinity and coastal ocean water temperatures.

"All lagoons in Southern California are at potential risk, as well as waters in Oregon, Washington and Mexico," Williams says. "San Francisco Bay is at high risk because it is a destination for 'live rock' shipped overseas for the aquarium trade." Live rock is coral covered with living marine organisms; Caulerpa has been found on live rock imports.

Based in part on a Sea Grant-funded survey of retail aquarium stores in Southern California, which found that $10 \%$ were selling an invasive strain of Caulerpa, the California Legislature in 2001 banned the importation, possession and intrastate sale of nine Caulerpa species. Interstate sale is illegal under the Noxious Weed Act of 1999.

The California Regional Water Quality Control Board led the eradication program, with the California Department of Fish and Game, California Department of Food and Agriculture (DFG), NMFS, U.S. Fish and Wildlife Service and California Sea Grant.

A biological consulting firm performed the eradication, which involved putting thick, black, plastic tarps over the Caulerpa patches, sealing them to the bottom and chlorinating the patches.

Despite the eradication program's success so far, Williams says, "Caulerpa has underground tissue, rhizoids, the algal equivalent of roots, that go 15 centimeters into the sediments." She believes the chlorine might not be reaching their roots.

Environmental factors such as water pollution and nutrient levels (see page 110) may also influence Caulerpa's ability to invade, Williams says. "Based on scientific studies in the Mediterranean and on my research, sea grass beds that are degraded are less resistant to Caulerpa invasion."

Ultimately, public outreach and education may be the key to stopping Caulerpa. "People need to know they cannot release the contents of their home aquariums into lagoons and harbors," says DFG biologist Bill Paznokas.

SCCAT advises not disturing a suspected Caulerpa outbreak, and reporting it immediately at (858) 467-2952. - Compiled from Sea Grant reports 